\title{
Observation of Vibrio mediterranei (Pujalte and Garay 1986) / Vibrio shiloi (Kushmaro et al. 2001) bacteria from skin ulcers of the cultured sea cucumber Holothuria poli (Delle Chiaje, 1823)
}

\section{Kültürü yapılan Holothuria poli (Delle Chiaje, 1823) türü deniz hıyarının deri ülserlerinden Vibrio mediterranei (Pujalte ve Garay 1986) / Vibrio shiloi (Kushmaro vd. 2001) bakterisinin gözlenmesi}

\author{
Mustafa Tolga Tolon $^{1 *}$ - Ulviye Karacalar ${ }^{2}$ - Caner Şirin ${ }^{3}$ \\ ${ }^{1}$ Ege University, Faculty of Fisheries, Aquaculture Department, 35040, Bornova, İzmir, Turkey \\ 2 Ege University, Faculty of Fisheries, Aquaculture Department, 35040, Bornova, İmir, Turkey \\ https://orcid.org/0000-0002-2233-0663 \\ 3 Ordu University, Faculty of Marine Science, Department of Fisheries Technology Engineering, Fatsa, Ordu, Turkey (D) https://orcid.org/0000-0001-6796-6852
}

\section{How to cite this paper:}

Tolon, M.T., Karacalar, U. \& Şirin, C. (2021). Observation of Vibrio mediterranei (Pujalte and Garay 1986) / Vibrio shiloi (Kushmaro et al. 2001) bacteria from skin ulcers of the cultured sea cucumber Holothuria poli (Delle Chiaje, 1823). Ege Journal of Fisheries and Aquatic Sciences, 38(3), 393-397. DOI: 10.12714/egejfas.38.3.16

Abstract: Skin ulcer syndrome is frequently reported as a serious disease affecting the health, growth and mortality of stocks in sea cucumber aquaculture. In this study, bacteria isolated predominantly from skin ulcers of sea cucumber Holothuria poli (Delle Chiaje, 1823), a new candidate for aquaculture in the Mediterranean, were investigated. Morphological and biochemical tests, and molecular analysis methods were used to examine the dominant bacteria in the lesions of $\mathrm{H}$. poli showing skin ulceration, peristome tumour and visceral ejection symptoms in rearing tanks. Present study is the first report for isolation and identification of Vibrio mediterranei (Pujalte and Garay 1986) (called also Vibrio shiloi Kushmaro et al. 2001) as a predominant gram-negative bacterium in the skin ulcers of $H$. poli. Reference data provided from the present study would lead to understand possible major pathogens causing skin ulceration syndrome and is crucial for the prophylaxis and treatment of such disease in holothuriculture.

Keywords: Bacteria, Holothuria poli, holothuriculture, sea cucumber, skin ulceration syndrome, Vibrio mediterranei, Vibrio shiloi

Öz: Deri ülseri sendromu deniz hıyarı yetiştiriciliğinde stokların sağlığını, büyümesini ve ölüm oranını etkileyen ciddi bir hastalık olarak sıkıkla rapor edilmektedir. Bu çalışmada, Akdeniz'de yetiştiricilik için yeni bir aday olan Holothuria poli (Delle Chiaje, 1823) türü deniz hıyarının deri ülserlerinden baskın halde izole edilen bakteriler incelenmiştir. Yetiştirme tanklarında deri ülseri, peristomal tümör ve bağırsak çıkarma semptomları gösteren deniz hıyarlarının deri lezyonlarındaki dominant bakterileri incelemek amacıyla morfolojik ve biyokimyasal testler, ve moleküler analiz yöntemleri kullanılmışıı. Bu çalıșma, $H$. polinin cilt ülserlerinde dominant gram-negatif bir bakteri olarak Vibrio mediterranei (Pujalte ve Garay 1986) 'nin (Vibrio shiloi Kushmaro vd. 2001 olarak da adlandırılı) izolasyonu ve tanımlanması konusunda ilk rapordur. Bu çalışmadan sağlanan referans veriler, deri ülseri sendromuna neden olan olası baskın patojenlerin anlaşılmasına yardımcı olurken deniz hıyarı kültüründe bu tür hastalıkların önlenmesi ve tedavisi için yol gösterici olması yönünden önemlidir.

Anahtar kelimeler: Bakteri, Holothuria poli, deniz hıyarı yetiştiriciliği, deniz hıyarı, deri ülseri sendromu, Vibrio mediterranei, Vibrio shiloi

\section{INTRODUCTION}

Sea cucumbers in all seas of the world, are in high demand and commercially exploited, particularly for food, cosmetics, and medical usage mainly by Far-East countries (Sicuro and Levine, 2011). Sea cucumber farming is reported as one of the fastest-growing aquaculture industries (Conand et al., 2014). Nearly fifteen species and more than 176500 tons (FAO, 2021) of sea cucumbers are produced in holothuriculture facilities particularly in China, Russian Federation Indonesia, Sri Lanka, Malaysia, Korea, Madagascar, Vietnam, New Caledonia, Zanzibar and Japan (Sicuro and Levine, 2011). Moreover, the temperate sea cucumber species like Holothuria tubulosa (Gmelin 1788), Holothuria poli (Delle Chiaje 1823), Holothuria forskali (Delle Chiaje, 1823), Holothuria arguinensis (Koehler and Vaney,
1906) and Holothuria mamata (Grube 1840) in the Atlantic and Mediterranean Sea are new candidates close to the commercial production level (Domínguez-Godino et al., 2015, Tonn et al., 2016, Tolon, 2017, Domínguez-Godino and González-Wangüemert, 2018, Rakaj et al., 2018, Rakaj et al., 2019).

The diseases of sea cucumbers that lead to mass mortality and significant economic loss in production farms are getting more important as a major factor limiting productivity (Li et al., 2012). Skin ulceration syndrome is the most critical disease among all, which is responsible for $95 \%$ of deaths in sea cucumber rearing tanks (Deng et al., 2009). The high infective disease has symptoms like decolorization 
of the skin, increased viscous mucus and lesions primarily formed on the mouth and cloacal openings of sea cucumbers. Becker et al., (2004), who first named this infection as "Skin Ulceration Syndrome", isolated and identified Vibrio sp., Bacteroides $s p$. and a-Proteobacterium type bacteria from the skin lesions of $H$. scabra by microscopic and biomolecular techniques. Vast majority of studies about skin ulceration syndrome are reporting various species of Vibrio genus as pathogenic bacteria in high-commercial sea cucumbers like H. scabra, Apostichopus japonicus (Selenka, 1867), and Isostichopus fuscus (Ludwig, 1875) (Wang et al., 2005, Ma et al., 2006, Wang, 2006, Zhang et al., 2006, Deng et al., 2008, Deng et al., 2009, Liu et al., 2010). However, it has been reported that Vibrio type bacteria isolated from skin lesions make the diagnosis and treatment of diseases difficult by hosting more than one strain according to sea cucumber species (Lane and Birkbeck, 1999; Choquet et al., 2003).

Vibrio mediterranei (former synonym for $V$. shiloi) are bacteria of the genus Vibrio isolated from bivalve populations, including oysters and mussels (Tarazona et al., 2014) and reported to cause significant mortality in other marine species (Kushmaro et al., 2001). Vibrio shiloi, first seen as the causative agent of bleaching disease of coral Oculina patagonica along the Israeli coastline, was later identified as a synonym for Vibrio mediteranei (Thompson et al., 2001).

There are limited or no studies on skin ulceration syndrome with sea cucumber species, particularly candidate for holothuriculture. However, case observations and mortality in breeding studies suggest that this disease affects these species as well as commercial ones. $H$. poli, a recent candidate for Mediterranean aquaculture, is one of these species which suffer from the skin ulceration syndrome in rearing conditions.

In this paper, predominant strains associated with the skin ulceration syndrome of the Mediterranean Sea cucumber, $\mathrm{H}$. poli were addressed for the first time. Therefore, bacteria isolated from the skin lesions of $H$. poli reared in aquaculture tanks were identified and characterised by using morphological and biochemical tests, and 16S rDNA gene sequence analysis in order to analyse the physiological and biochemical characteristics of the predominant strains. Reference data provided from the present study would help to understand possible pathogen bacteria associated with the skin ulceration syndrome and crucial for the prophylaxis and treatment of such disease in holothuriculture.

\section{MATERIAL AND METHODS}

\section{Sampling and physiologic - biochemical characterization of the bacteria}

Adult sea cucumber $H$. poli individuals $(92 \pm 2.4 \mathrm{~g}$ ) showing symptoms of skin ulceration, peristome tumescence, visceral ejection or in moribund condition were collected from the rearing tanks of the aquaculture facility in Ege University, Faculty of Fisheries, Urla Research Unit (Izmir, Turkey). The water parameters in recirculating aquaculture system were 22-26 $\mathrm{C}^{\circ}, 38-40$ ppm salinity, 6.8-7.0 ppm dissolved oxygen and $8,00 \mathrm{pH}$.

Tissue samples were taken from the skin lesions, mucous and coelomic fluid of 15 dissected sea cucumbers under sterile conditions. In order to prevent the external contamination of the samples by microorganisms and aquatic microflora, the skin of the sea cucumbers and the tools were treated by $98 \%$ ethanol, prior to sampling. Samples were streaked onto the Tryptone Soy Agar (TSA, Oxoid-CM0131) containing $1.5 \% \mathrm{NaCl}(\mathrm{w} / \mathrm{v})$ and Thiosulphate-Citrate-Bile Salt-Sucrose agar (TCBS, Difco). All cultures incubated at 25 $\pm 2{ }^{\circ} \mathrm{C}$ for 24 - 48 hours. Following the incubation period, the suspected colonies (yellow and green) selected and streaked onto TCBS agar to ensure the purity of the culture. Morphologic and biochemical tests like cytochrome oxidase, resistance to $0 / 129(10 \mu \mathrm{g})$, gram staining, catalase, Triple Sugar Iron Agar (TSI), Voges-Proskauer (VP), citrate utilization, indole production, gelatinase, ONPG and decarboxylase of amino acids were performed to identify the selected culture (Bergey et al., 1939, Alsina and Blanch, 1994). Phenotypic characterization of the isolate was performed by API 20 E Identification Strip (Bio Merieux).

\section{DNA extraction, PCR amplification and sequencing}

DNA was performed from pure cultures of the bacteria using Roche High Pure PCR Template Preparation kit according to the manufacturer's instructions. Amplification of the 16S rDNA gene fragments were achieved using universal 16S rDNA bacterial primers: 27F (5'AGAGTTTGATCCTGGCTCAG-3') and 1492R (5'TACGGCTACCTTGTTACGACTT-3') and Taq DNA polymerase kit (HelixAmpTM). PCR was conducted in $50 \mu \mathrm{l}$ reaction volumes containing $1 \mu \mathrm{l}$ of each primer, $1 \mu \mathrm{l}$ of each dNTP, $5 \mu \mathrm{l} 10 \times$ Taq polymerase buffer, $10 \mu \mathrm{l} 5 \times$ Tune-Up Buffer, 1.25 units of Taq polymerase, $5 \mu \mathrm{LNA}$, and molecular grade water. PCRs were run on SimpliAmp Thermal Cycler (Applied Biosystem), with initial denaturation at $95^{\circ} \mathrm{C}$ for 2 minutes, followed by 35 cycles of $95^{\circ} \mathrm{C}$ for 20 seconds, $53{ }^{\circ} \mathrm{C}$ for 40 seconds, and $72{ }^{\circ} \mathrm{C}$ for 90 seconds. The final elongation step performed at $72^{\circ} \mathrm{C}$ for $5 \mathrm{~min}$. PCR products were electrophoresed in a $1 \%$ agarose gel in $1 \times$ Tris-borate-EDTA (TBE) buffer stained with GelRed. The PCR amplification products were purified and sequenced by AltigenBio Laboratories (Izmir, Turkey). The sequencing reactions were performed using an $\mathrm{ABI} 3730$ DNA analyser (Applied Biosystem).

Sequences were assembled using the BioEdit 7.0.5.2 (Hall, 1999) and consensus sequence was compared with other bacterial 16S rDNA sequences for DNA similarity in the GenBank database of the National Centre for Biotechnology Information (NCBI) by the nucleotide Basic Local Alignment Search Tool (BLAST) searches. 

(Delle Chiaje, 1823)

\section{RESULTS}

\section{Symptomatic observation}

Symptomatic observations in sea cucumber rearing tanks showed similar signs of disease in all sea cucumbers with skin ulceration disease. The symptoms characterized as anorexia, constipation, loss of adhesion ability to the substrates and inertia in very early stages of the disease. The body colour returns to matte palish brown and lost its vibrancy. Dense increase in viscous mucous secretion covering the whole-body surface was the most characteristic sign related with the skin ulceration syndrome. Ulcer spots were appeared primarily on the mouth and cloacal openings and spread to the various parts of the body. In mid stages, infected sea cucumbers became motionless, stop feeding completely and eviscerated their viscera. The body wall became flat and extremely soft without any muscular response to physical contact (Figure 1).

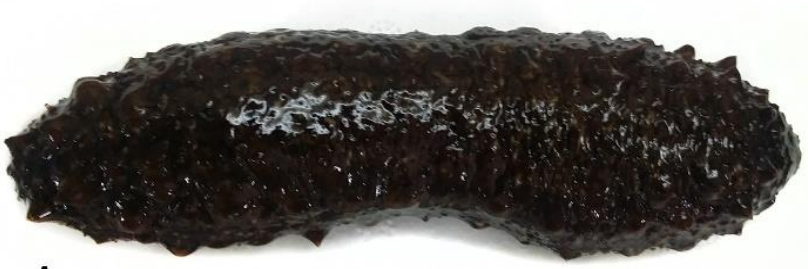

A

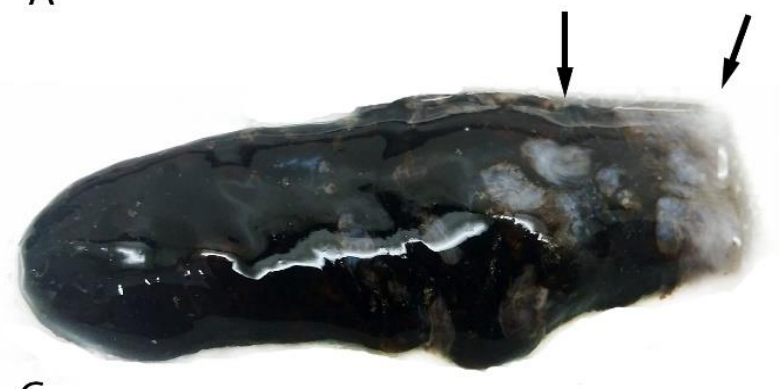

C

$\mathrm{E}$

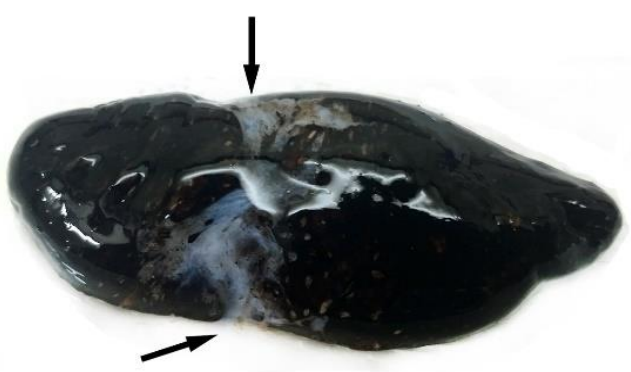

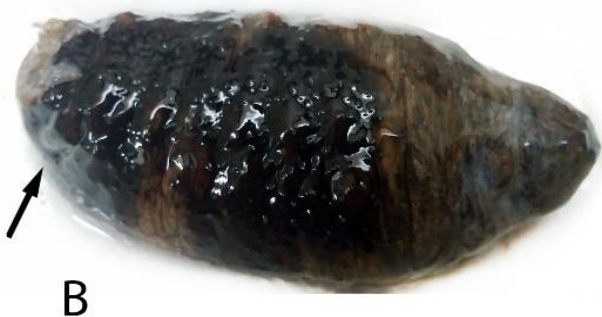

B
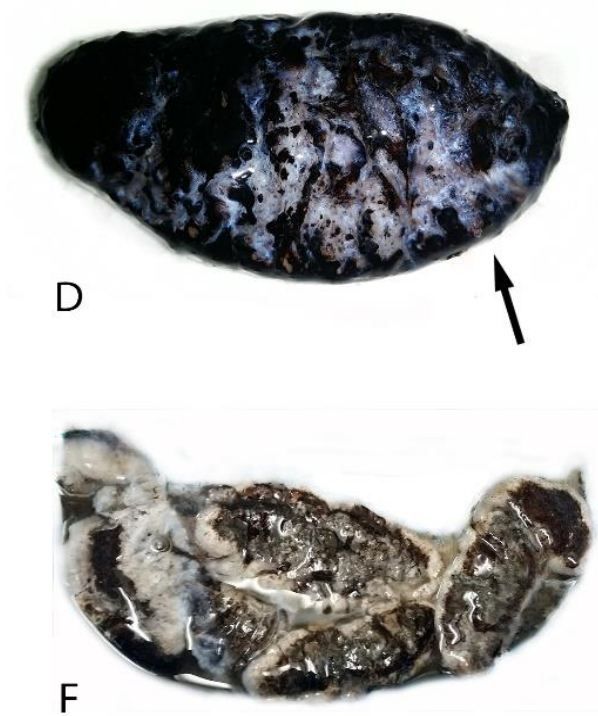

Figure 1. Arrows indicated lesions on the skin; A: healthy sea cucumber; B: early stage of ulceration close to cloacal opening; C: viscous mucus covering the whole-body wall and lesion patches close to mouth; D and E: ulceration on body wall; F: ulceration on whole body

The last stage of the disease characterised by extreme mucus secretion, dense white lesions covered the whole body, mass erosion of body wall and death within 3 to 5 days. Symptoms are observed on several sea cucumber individuals in various stages however, after the first appearance of the disease, there was a rapid increase in the number of sea cucumbers showing symptoms of the skin ulceration syndrome.

\section{Bacterial morphology and biochemical characters}

Biochemical characterization was established by detecting the dominant bacterial isolate in the streaking results from the body tissues and coelomic fluid of the infected sea cucumbers reared at $22-26{ }^{\circ} \mathrm{C}$. It was determined that the cultured bacteria were highly homogenous and the isolated colonies in the TCBS agar were yellow, round, and smooth, and the bacteria cells were gramnegative. The reactions to indole, glucose, mannitol, sorbitol, melibiose, sucrose, melibiose, amylose, oxidase and catalase were positive; however, arginine dihydrolase, lysine decarboxylase ornithine decarboxylase, citrate, $\mathrm{H}_{2} \mathrm{~S}$, urease, Voges-Proskauer, gelatinase, inositol, rhamnose and arabinose reactions were negative. Based on morphological and biochemical analyses, the dominant bacterium isolated from the skin ulcers of infected Holothuria poli was identified as Vibrio mediterranei / Vibrio shiloi. 


\section{Molecular analysis}

The universal primers successfully amplified $1427 \mathrm{bp}$ fragment of the 16S rDNA gene fragment from one isolate. In sequence similarity analysis using BLASTn tool, the sequence of the present Vibrio species isolate showed $100 \%$ the highest similarity with other $V$. mediterranei strains (MN874182, MN843962, MN843755, HF541963, JQ409387, MT860483, KX904712, MK452737.1, KM041189) and with uncultured Vibrio sp. (MG554521) and $99.51 \%$ the minimum similarity with Vibrio shiloi strain S0901 (HQ658895).

\section{DISCUSSION}

Skin ulceration syndrome is an important epidemic infection that is the most common in sea cucumber aquaculture. In previous studies, Pseudoalteromonas nigrifacien, Vibrio tapetis, Vibrio splendidus, Marinomonas dokdonensi (Deng et al., 2008), Shewanella sp., Pseudoalteromonas tetraodonis (Liu et al., 2010), Vibrio alginolyticus (Zhang et al., 2015), Aeromonas salmonda and Aeromonas media (Wang et al., 2007) have been reported as the bacteria isolated from the skin ulcers of infected sea cucumbers in aquaculture tanks. Liu et al., (2010) reported Pseudoalteromonas sp. and Pseudoalteromonas tetraodonis as the pathogenic bacteria responsible for the skin ulceration syndrome in experimental or naturally infected Apostichopus japonicus individuals, however, the healthy Holothuria scabra adults used in the same study failed to be experimentally infected with those bacteria. All findings derived from those studies are indicating Vibrio species, as the major pathogenic agent of skin ulceration syndrome (Becker et al., 2004, Wang et al., 2005).

In the current study, Mediterranean-specific $V$. mediterranei / $V$. shiloi were isolated for the first time from the skin ulcers of $H$. poli, which suggests that the different bacteria species would be effective in skin ulceration syndrome among the geographical regions. Vibrio mediterranei was first reported in 1992 (Pujalte et al., 1992) to cause coral albinism but harmless to humans and animals. However, this study revealed that the mentioned bacterium is predominantly present in the skin ulcers of Holothuria poli and would be susceptible from the disease.

\section{REFERENCES}

Alsina, M. \& Blanch, A.R. (1994). Improvement and update of a set of keys for biochemical identification of Vibrio species. Journal of Applied Bacteriology, 77(6), 719-721. DOI: 10.1111/j.1365-2672.1994.tb02824.x

Becker, P., Gillan, D., Lanterbecq, D., Jangoux, M., Rasolofonirina, R., Rakotovao, J. \& Eeckhaut, I. (2004). The skin ulceration disease in cultivated juveniles of Holothuria scabra (Holothuroidea, Echinodermata). Aquaculture, 242(1-4), 13-30. DOI: $10.1016 / j$.aquaculture.2003.11.018

Bergey, D.H., Breed, R.S., Murray, E.G.D. \& Hitchens, A.P. (1939). Bergey's Manual of Determinative Bacteriology. Fifth Edn. The Williams and Wilkins Company, Baltimore.

Choquet, G., Soudant, P., Lambert, C., Nicolas, J.L. \& Paillard, C., (2003). Reduction of adhesion properties of Ruditapes philippinarum hemocytes
V. mediterranei $\mathrm{V}$. shiloi has a wide range of identification from marine sediments, planktons, bivalves (mussels, oysters, and crustaceans), marine invertebrates (corals, sponges, shrimps, and sea urchins), and fish (shield, amberjack, and spotted rose snapper), however, a limited number of studies has identified this bacteria strain as a pathogenic agent in marine organisms. León-Palmero et al., (2018) have identified $V$. mediterranei in the feces of healthy sea cucumbers, $H$. tubulosa, and $H$. forskali, sampled from the experimental aquaculture tanks but could not successfully associate with any disease. It is considered that $V$. mediterranei / V. shiloi, which is frequently present in the marine environment, may be effective in skin ulceration syndrome with the effect of high-water temperatures (23$25^{\circ} \mathrm{C}$ ) in the aquaculture environment. Similarly, Toren et al., (1998) reported that $V$. mediterranei, the bleaching agent in Oculina patagonica corals in the Mediterranean had no effect at $16^{\circ} \mathrm{C}$ but became more virulent with the increasing water temperature $\left(23-29^{\circ} \mathrm{C}\right)$. Also in this study, V. mediterranei / $V$. shiloi was isolated from $H$. poli reared in high water temperatures like $22-26^{\circ} \mathrm{C}$. However, the effect of different water temperatures and other abiotic variables on the virulence of this bacteria should be examined in further studies.

In this study, V. mediterranei / V. shiloi was reported for the first time in literature as the dominant bacterium, isolated from the skin ulcers of Mediterranean Sea cucumber, $H$. poli. The analysis of $16 \mathrm{~S}$ rDNA gene sequence similarity of BLAST search revealed that the present Vibrio species isolate was showed the highest similarity ranging from $99.51 \%$ to $100 \%$ to all other $V$. mediterranei strains. Disease symptoms, morphology and biochemical characters of bacteria also support that the identified Vibrio species is the V. mediterranei / V. shiloi.

Information derived from this study suggests that different bacterial isolates would be effective on skin ulceration syndrome of sea cucumbers among the species and geographical regions. Therefore, future studies about skin ulceration syndrome should be conducted as specific to the species and geographical locations.

exposed to Vibrio tapetis. Diseases of Aquatic Organisms, 57 (1-2) (2003), 109-116. DOI: 10.3354/dao057109

Conand, C., Shea, S. \& To, A. (2014). Beche-de-mer trade statistics for Hong Kong in 2012. SPC Beche-de-mer Information Bulletin, 34, 43-46.

Choquet, G., Soudant, P., Lambert,C., Nicolas, J.L. \& Paillard, C., (2003). Reduction of adhesion properties of Ruditapes philippinarum hemocytes exposed to Vibrio tapetis. Diseases of Aquatic Organisms, 57 (1-2) (2003), 109-116. DOI:10.3354/dao057109

Deng, H., Zhou, Z.C., Wang, N.B. \& Liu, C. (2008). The syndrome of sea cucumber (Apostichopus japonicus) infected by virus and bacteria. Virologica Sinica, 23(1), 63-67. DOI: 10.1007/s12250-008-2863-9

Deng, H., He, C., Zhou, Z., Liu, C., Tan, K., Wang, N., Liu, W. (2009). Isolation and pathogenicity of pathogens from skin ulceration disease 
and viscera ejection syndrome of the sea cucumber Apostichopus japonicus. Aquaculture, 287(1-2), 18-27. DOI: 10.1016/j.aquaculture.2008.10.015

Domínguez-Godino, J.A., Slater, M.J., Hannon, C. \& González-Wangüermert, M. (2015). A new species for sea cucumber ranching and aquaculture: Breeding and rearing of Holothuria arguinensis. Aquaculture, 438, 122128. DOI: 10.1016/j.aquaculture.2015.01.004

Domínguez-Godino, J.A., \& González-Wangüemert, M. (2018). Breeding and larval development of Holothuria mammata, a new target species for aquaculture. Aquaculture Research, 49(4), 1430-1440. DOI: 10.1111/are.13597

FAO. (2021). Fishery and Aquaculture Statistics. Global aquaculture production 1950-2019 (FishstatJ). In: FAO Fisheries Division [online]. Rome. Updated 2021. www.fao.org/fishery/statistics/software/fishstatj/en

Hall, T.A. (1999) BioEdit: A User-Friendly Biological Sequence Alignment Editor and Analysis Program for Windows 95/98/NT. Nucleic Acids Symposium Series, 41, 95-98.

Kushmaro, A., Banin, E., Loya, Y., Stackebrandt, E. \& Rosenberg, E. (2001). Vibrio shiloi sp. nov., the causative agent of bleaching of the coral Oculina patagonica. International journal of systematic and evolutionary microbiology, 51(4), 1383-1388. DOI: 10.1099/00207713-51-4-1383

Lane, E. \& Birkbeck, T.H. (1999). Toxicity of bacteria towards haemocytes of Mytilus edulis Aquatic Living Resources, 12(1999), 343-350. DOI:10.1016/S0990-7440(99)00113-8

León-Palmero, E., Joglar, V., Álvarez, P.A., Martín-Platero, A., Llamas, I. \& Reche, I. (2018). Diversity and antimicrobial potential in sea anemone and holothurian microbiomes. PloS one, 13(5), e0196178. DOI: 10.1371/journal.pone.0196178

Li, C.H., Feng, W.D., Qiu, L.H., Xia, C.G., Su, X.R., Jin, C.H., Zhou, T.T., Zeng, Y. \& Li, T.W. 2012. Characterization of skin ulceration syndrome associated microRNAs in sea cucumber Apostichopus japonicus by deep sequencing. Fish and Shellfish Immunology, 33 (2), 436-441. DOI: 10.1016/j.fsi.2012.04.013

Liu, H., Zheng, F., Sun, X., Hong, X., Dong, S., Wang, B., ... Wang, Y. (2010). Identification of the pathogens associated with skin ulceration and peristome tumescence in cultured sea cucumbers Apostichopus japonicus (Selenka). Journal of Invertebrate Pathology, 105(3), 236-242. DOI: 10.1016/j.jip.2010.05.016

Ma, Y., Xu, G., Chang, Y., Zhang, E. P., Zhou, W. \& Song, L. S. (2006). Bacterial pathogens of skin ulceration disease in cultured sea cucumber Apostichopus japonicus (Selenka) juveniles. Journal of Dalian Fisheries University, 21(1), 13-18.

Pujalte, M.A., Ortiz-Conde, B.A., Steven, S.E., Esteve, C., Garay, E. \& Colwell, R.R. (1992) Numerical taxonomy and nucleic acid studies of Vibrio mediterranei. Systematic Applied Microbiology, 15 (1992), 82-91. DOI: 10.1016/S0723-2020(11)80143-8

Rakaj, A., Fianchini, A., Boncagni, P., Lovatelli, A., Scardi, M. \& Cataudella, S. (2018). Spawning and rearing of Holothuria tubulosa: A new candidate for aquaculture in the Mediterranean region. Aquaculture Research, 49(1), 557-568. DOI: 10.1111/are.13487

Rakaj, A., Fianchini, A., Boncagni, P., Scardi, M. \& Cataudella, S. (2019). Artificial reproduction of Holothuria polii: A new candidate for aquaculture. Aquaculture, 498, 444-453. DOI: 10.1016/j.aquaculture.2018.08.060

Saravanan, S. \& Sivakami, R. (2018) Identification of Vibrio species occurring in food fishes and studies on their antibiotic resistances. International Journal of Zoology and Applied Biosciences, 3,318-32.

Sicuro, B. \& Levine, J. (2011). Sea cucumber in the Mediterranean: a potential species for aquaculture in the Mediterranean. Reviews in Fisheries Science, 19(3), 299-304. DOI: 10.1080/10641262.2011.598249

Tarazona, E., Lucena, T., Arahal, D.R., Macián, M.C., Ruvira, M.A. \& Pujalte, M.J. (2014) Multilocus sequence analysis of putative Vibrio mediterranei strains and description of Vibrio thalassae sp. Systematics of Applied Microbiology, 37 (5), 320-328.

DOI: 10.1016/j.syapm.2014.05.005

Thompson, F.L., Hoste, B., Thompson, C.C, Huys, G. \& Swings, J. (2001) The coral bleaching Vibrio shiloi Kushmaro et al. 2001 is a later synonym of Vibrio mediterranei Pujalte and Garay 1986 Systematic Applied Microbiology., 24 (4), 516-519, DOI: 10.1078/0723-2020-00065

Tolon, T. (2017). Effect of salinity on growth and survival of the juvenile sea cucumbers Holothuria tubulosa (Gmelin, 1788) and Holothuria poli (Delle Chiaje, 1923). FEB-Fresenius Environmental Bulletin, 26(6), 3930-3935.

Tonn, N., Novais, S.C., Silva, C.S., Morais, H.A., Correia, J.P. \& Lemos, M.F. (2016). Stress responses of the sea cucumber Holothuria forskali during aquaculture handling and transportation. Marine Biology Research, 12(9), 948-957. DOI: 10.1080/17451000.2016.1218030

Toren, A., Landau, L., Kushmaro, A., Loya, Y. \& Rosenberg, E. (1998). Effect of temperature on adhesion of Vibrio strain ak-1 to Oculina patagonica and on coral bleaching. Applied and Environmental Microbiology, 64(4), 1379-1384. DOI: 10.1128/AEM.64.4.1379-1384.1998

Wang, Y.G., Rong, X.J., Zhang, C.Y. \& Sun, S. (2005). Main diseases of cultured Apostichopus japonicus: prevention and treatment. Marine Sciences, 29(3), 1-7.

Wang, Y. (2006). Etiology of skin ulcer syndrome in cultured juveniles of Apostichopus japonicus and analysis of reservoir of the pathogens. Journal of Fishery Sciences of China/Zhongguo Shuichan Kexue, 13(4), 610-616.

Wang, G.X., Yuan, J.L., Zhao, Y.K. \& Yuan, M. (2007). Isolation, identification and drug sensitivity of the pathogens of the skin ulceration disease in Apostichopus japonicus. Journal of Northwest $A$ and $F$ University (Natural Science Edition), 35, 87-90.

Zhang, C.Y., Wang, Y.G. \& Rong, X.J. (2006). Isolation and identification of causative pathogen for skin ulcerative syndrome in Apostichopus japonicus. Journal of Fisheries China, 30(1), 118-123.

Zhang, J., Cao, Z., Li, Z., Wang, L., Li, H., Wu, F., Xu, Y. (2015). Effect of bacteriophages on Vibrio alginolyticus infection in the sea cucumber, Apostichopus japonicus (Selenka). Journal of the World Aquaculture Society, 46(2), 149-158. DOI: 10.1111/jwas.12177 